\title{
New proposal for the treatment of poor prognosis young patients with advanced stage diffuse large B-cell lymphoma
}

\author{
Nova proposta de tratamento no linfoma difuso de grandes células $B$ no paciente jovem de \\ mau prognóstico em estágio avançado
}

Sergio Cortelazzo ${ }^{1}$

\begin{abstract}
Patients with DLBCL now have a better outcome with a longer survival because of two major developments: 1) increasing the dose of active drugs with shortening the time between cycles, resulting in dose-dense or dose-intense regimens; and 2) combining rituximab with chemotherapy. Both strategies were associated with a better clinical outcome, particularly in patients without adverse prognostic factors. Poor risk patients in the age range of 60 to 65 years may benefit from a combination of dose-dense or dose-intense regimens plus rituximab. Young patients with poor risk DLBCL defined by an aaIPI of 2 or 3 and age younger than 60 years, are characterized by truly refractory disease, evidenced by progression during or early after treatment, or later relapse. Attempts to modify treatment including immunotherapy to improve the response rate and reduce the proportion of patients with progressive disease have been only partially successful: to date: the best progression-free survival was 51\%. In contrast, some attempts to decrease the high resistant and relapse rate with sequential high-dose chemotherapy with rituximab (R-HDS) and autologous stem cell transplantation (ASCT) have succeeded. On the basis of these promising results, GITIL launched a prospective phase III randomized trial comparing the efficacy and safety of dose-dense CHOP plus rituximab with R-HDS and ASCT. Preliminary data show that intensive programs such as dose-dense chemo-immunotherapy and R-HDS with ASCT are feasible until 65 years with a manageable toxic profile, also on multi-centre basis. Rev. bras. hematol. hemoter. 2008; 30(Supl. 2):50-54.
\end{abstract}

Key words: Diffuse large B-cell lymphoma; treatment; prognostic.
Diffuse large B-cell lymphoma (DLBCL) is the most frequent non-Hodgkin's lymphoma (NHL) subtype in western countries, accounting for about $30 \%$ to $35 \%$ of all cases. It is characterized as an aggressive lymphoma because survival is limited in the absence of effective treatment. Currently, DLBCL may be cured in a significant percentage of patients, depending on the initial characteristics of the tumor and the host.

Patients with advanced stages (stage $\geq$ II B, bulky, III, IV), who represent about one third of all cases of DLBCL, generally had an high rate of resistance and relapse after conventional chemotherapy. Therefore, several phase II study proposed different therapeutic regimens for improving the survival of these poor risk patients. The study that defined the chemotherapy standard was an Intergroup trial conducted by Southwest Oncology Group (SWOG) and Eastern Cooperative Oncology Group (ECOG). In this study, previously untreated patients with stages II bulky, III, and IV disease with aggressive histology were randomized to one of four treatment arms: CHOP, m-BACOD, ProMACECytaBOM, or MACOP-B. ${ }^{1}$ Actual 5-year failure free survival (FFS) varied from $33 \%$ and $38 \%$ and 5 -year overall survival (OS) ranged between $45 \%$ and $46 \%$. None of those differences among the treatment arms were significant. However, when fatal and life-threatening reactions were combined, significant differences were found between

Gruppo Italiano Terapie Innovative nei Linfomi (GITIL)

Correspondence: Sergio Cortelazzo

Gruppo Italiano Terapie Innovative nei Linfomi (GITIL), Division of Hematology and BMT of General Hospital of Bolzano, Italy.

E-mail:sergio.cortelazzo@asbz.it 
regimens, with CHOP and ProMACE-CytaBOM being less toxic than m-BACOD and MACOP-B. These results, along with the fact that $\mathrm{CHOP}$ was cheaper and easier to administer than the other regimens, established CHOP as the standard therapy throughout the world. However, with a projected disease-free survival rate of $36 \%$ it is obvious that it is far from ideal therapy, and there is clearly a need for better treatment approaches.

Disparate results occurring between the single institution Phase II studies and the subsequent national Phase III trial ca be explained by the heterogeneity of DLBCL, as identified in the current classification schemes. The International Non-Hodgkin's Lymphoma Prognostic Factors Index (IPI) utilized pretreatment prognostic factors in a sample of over 5,000 patients to develop a predictive model of outcome for DLBCL. ${ }^{2}$ The majority of patients had received adriamycin-based chemotherapy regimens: Five pretreatment characteristics were found to be independent predictors of death: age ( $<60 \mathrm{vs.}>60)$, tumor stage I-or II (localized) vs. III or IV (advanced), the number of extranodal sites of involvement ( $<1 \mathrm{vs} .>1)$, patient ECOG performance status ( 0 or 1 ambulatory) vs. $>2$ (non ambulatory) and serum lactate dehydrogenase (LDH) level ( less than or equal to 1 times normal vs. $>1$ times normal). Each of the individual factors had comparable relative risks and thus could be summed together. The resulting model identified 4 risk groups with associated 5-year survival rates: low-risk (0-1, risk factors), $73 \%$; low intermediate risk ( 2 risk factors), $51 \%$; high intermediate risk (3 risk factors), $43 \%$; and high risk (4-5 risk factors), $26 \%$. In 1.274 patients 60 or younger, an age-adjusted model (aaIPI) based on tumor stage, lactate dehydrogenase level and performance status identified four risk groups with predicted 5-year survival rates of $83 \%, 69$ $\%, 46 \%$ and $32 \%$. In both models, the increased risk of death was due to both a lower rate of complete responses and higher rate of relapse from complete response. The differences in outcome caused by these imbalances in patient prognostic factors can easily exceed any treatment differences.

Currently, attempts are being made to define the prognosis of biologically defined subsets of patients with DLBCL. The Leukemia-Lymphoma Molecular Profiling Project (LLMP) has used complementary-DNA (cDNA) microarray techniques to demonstrate two distinct subpopulations of DLBCL with different prognosis and different genetics. Patients with a germinal canter (GC) B cell-like signature have a more favorable course than those with an activated B cell like profile. ${ }^{3}$ These differences exist within each risk group identified by IPI. Although microarray technique have advanced understanding of the biology of lymphoid malignancy and have allowed the prognostic groups identified by the IPI to be further refined, their clinical utility is limited by the requirement for fresh or optimally cryopreserved samples, and by high costs. Tissue microarray
(TMA) technology has recently provided further prognostic information in DLBCL. This technique allows simultaneous, high through-put immunohistochemical analysis of protein expression in multiple specimens on a single slide, allowing the identification of protein surrogates for genes identified as being dysregulated in GEPs. These can be performed on routine in formalin-fixed and paraffin-embedded clinical samples. Hans and colleagues ${ }^{4}$ have reported results from a TMA containing 152 DLBCL cases, of which 142 had been previously evaluated using cDNA microarrays and confirmed the potential for TMAs to determine possible immunohistochemical surrogates for GEP studies. However, one of the largest potential limitations of the GEP and TMA studies to date is that these are based on patient samples obtained before the widespread use of rituximab in the treatment of DLBCL. Several studies have demonstrated that prognostic factors in DLBCL can be modified by therapy and new studies are therefore in progress based on material from patients with DLBCL treated uniformly with CHOP and rituximab. Until then, the IPI should still considered the standard system for risk stratification in this disease, particularly since its value as a prognostic model appears to be maintained for patients in the relapsed setting as well as those who are previously untreated.

As formerly mentioned, the US Intergroup Study ${ }^{1}$ had confirmed the CHOP regimen as standard care. However, CHOP resulted in only a $30 \%-40 \%$ of OS at 5 years, and $30 \%$ of patients failed to respond or progressed shortly after the completion of treatment. These outcomes prompted the investigation of dose-dense or dose-intense strategies to improve response rates or consolidation with high-dose therapy (HDT) and autologous stem cell transplantation (ASCT) to decrease the relapse rate. In 1993 the German High-Grade Non-Hodgkin's Lymphoma Study Group (DSHNHL) evaluated CHOP administered on a 2-(CHOP14) or 3-weeks (CHOP-21) schedule and the addition of etoposide (CHOEP), also on a 2- or 3-week schedule, in young (18 to 60 years) (NHL-B1) and elderly ( $>60$ years) (NHL-B2) patients with good-prognosis (normal LDH) aggressive lymphoma. ${ }^{5,6}$ About two third of the study group had an IPI of 0 . The dose-dense schedule of CHOP-14 prolonged the event-free (EFS) and overall-survival (OS) in elderly patients, and provided a significant benefit with respect to OS in young patients. The addition of etoposide to the $\mathrm{CHOP}$ resulted in a higher rate of complete remissions and a significant improvement of event-free survival (EFS), but similar OS, after 5 years in young patients with good prognosis aggressive lymphoma.

A second novel therapeutic approach involved the use of ASCT as part of the initial treatment regimen. Highdose chemotherapy followed by ASCT was shown to provide significant advantage regarding EFS and OS in patients with chemosensitive relapses of aggressive NHL after conventional therapy in the PARMA study. ${ }^{7}$ These 
results encouraged many investigators to apply HDT already as part of first-line therapy and indeed this approach generated promising results in phase II trials..$^{8-10}$ Subsequently, several prospective randomized trials compared HDT to conventional therapy in patients with aggressive lymphoma yielding conflicting results. Taken into account that most of these studies had methodological weakness, a recent meta analysis showed no overall differences in terms of OS and EFS in patients with aggressive NHL receiving either conventional chemotherapy or HDT. ${ }^{11}$ However, there were differences between different risk groups stratified according to IPI: Patients with good risk had better overall outcome after conventional chemotherapy. Therefore, HDT should not be further investigated in good risk patients with aggressive NHL, but high quality study should be designed in poor risk patients.

After the demonstration of the activity of rituximab in aggressive B-cell lymphomas in two phase II studies ${ }^{12,13}$ one with rituximab alone in relapsing patients and the other with rituximab and CHOP (R-CHOP) in untreated patients, several groups launched randomized trials in different patient subsets to test the ability of R-CHOP to increase the cure rate over CHOP alone in DLBCL. Three prospective randomized studies evaluated the role of R-CHOP in elderly patients with aggressive NHL. The GELA group randomized 399 previously untreated patients with DLBCL, 60 to 80 years old, to receive either 8 cycles of CHOP every 3 weeks or 8 cycles of CHOP plus rituximab given on day 1 of each cycle. ${ }^{14}$ Complete response rates of $76 \%$ and $63 \%(\mathrm{P}=0.005)$ and 2-year $\mathrm{OS}$ of $70 \%$ and $57 \%(\mathrm{P}=0.007)$ were achieved by $\mathrm{R}-\mathrm{CHOP}$ and $\mathrm{CHOP}$, respectively. The incidence of severe or serious side effects was similar in the two treatment arms. The outcome in different risk groups according to IPI suggested that addition of rituximab therapy to standard CHOP may lead to significant prolongation of EFS and OS in elderly patients with both high-risk and low-risk disease with no increase in toxicity. The results from GELA are currently the more mature, with a 5 -year median follow-up. ${ }^{15}$ Nearly half of R-CHOP patients were event free at 5 years, compared with $28 \%$ in the CHOP arm. EFS, PFS, DFS and OS, remained statistically significant in favor of the combination of R-CHOP. The benefit from R-CHOP was observed in both low-risk and high-risk IPI groups. No longterm toxicity appeared to be associated with the R-+CHOP combination. The second study, the US Intergroup E 4494 study from ECOG and Cancer and Leukemia Group B (CALGB) with participation from SWOG randomized a similar population of elderly patients to receive initial therapy with either CHOP or CHOP with rituximab. ${ }^{16}$ Responding patients then were randomized to receive either rituximab maintenance therapy (MR) or no maintenance. Three-year FFS rate was $53 \%$ for R-CHOP patients and $46 \%$ for CHOP $(\mathrm{P}=0.04)$ after a median follow-up time of 3.5 years. Two- year FFS rate from second random assignment was $76 \%$ for MR compared with $61 \%$ for observation $(\mathrm{P}=0.009)$. No significant differences in survival were seen according to induction or maintenance therapy. FFS was prolonged with MR after CHOP, but not after R-CHOP. In a secondary analysis excluding MR patients, $\mathrm{R}-\mathrm{CHOP}$ alone reduced the risks of treatment failure and death compared with $\mathrm{CHOP}$ alone. These data showed that rituximab administered as induction or maintenance with $\mathrm{CHOP}$ chemotherapy significantly prolonged FFS in older DLBCL patients. After $\mathrm{R}-\mathrm{CHOP}$, no benefit was provided by MR. The third trial leaded by DSHNHL (RICOVER-60). ${ }^{17}$ assessed whether six or eight cycles of R-CHOP-14 can improve outcome of patients aged 61-80 years with DLBCL. Six cycles of R-CHOP14 significantly improved event-free, progression-free, and overall survival over six cycles of CHOP-14 treatment. The advantage was particularly high in patients with unfavorable presentation. This study suggested that response-adapted addition of chemotherapy beyond six cycles, though widely practiced, is not justified and six cycles of R-CHOP-14 is the preferred treatment for elderly patients, with which other approaches should be compared.

However, until recently, there were no phase III studies addressing the value of rituximab in younger patients. The MabThera International Trial (MinT) randomized 824 patients, aged $18-60$ years, with $0-1$ aaIPI risk factors, and with or without bulky disease to six cycles of CHOP-like chemotherapy and rituximab or to six cycles of CHOP-like chemotherapy alone. ${ }^{18}$ After a median follow-up of 34 months, patients assigned to chemotherapy and rituximab had increased 3-year EFS compared with those assigned to chemotherapy alone ( $79 \%$ vs. $59 \% ; \mathrm{P}=0.0001)$ and had increased 3 -year OS ( $93 \%$ vs. $84 \%$; $\mathrm{P}=0.0001)$. EFS was affected by treatment group, presence of bulky disease and aaIPI. In fact, after chemotherapy and rituximab a favorable subgroup (ie, aa IPI $=0$, no bulk) could be defined from less favorable subgroup (ie, aaIPI=1 or bulk or both).

This is the first randomized trial supporting the use of rituximab in younger patients, albeit a selected subset of younger patients with good-prognosis DLBCL. However, it did not deal with the poor-prognosis subset of younger patients. In fact, the addition of rituximab to CHOP chemotherapy has lead to a marked improvement in survival of patients with favorable presentation according to IPI, which has been revised by Sehn and colleagues ${ }^{19}$ for patients receiving immune-chemotherapy (R-IPI), but those with high R-IPI score still had a 4-year PFS and OS of 53\% and $55 \%$, respectively. These outcomes prompted many centers to investigate the combination of rituximab with high-dose chemotherapy and autologous stem cell transplantation as front-line treatment of this poor risk patients. Il Gruppo Italiano Terapie Innovative nei Linfomi (GITIL) enrolled 112 patients, aged less than 65 years, with 2-3 aaIPI risk factors, in a chemotherapeutic program 
consisting in the combination of rituximab and high-dose (hd) sequential chemotherapy delivered with multiple autologous peripheral blood progenitor cell (PBPC) support (R-HDS regimen). ${ }^{20}$ Overall $80 \%$ of patients reached $\mathrm{CR}$ and after a median follow-up of 48 months $73 \%$ of cases were alive in continuous $\mathrm{CR}$, with a 4-year OS and EFS projections of $76 \%$ and $73 \%$. It was noteworthy that no differences in OS and EFS were found between subgroups with germinalcenter and activated B-cell phenotype. Thus, these results suggested that life-expectancy of younger patients belonging to high-risk aaIPI subgroup can be improved with the early administration of rituximab-supplemented intensive chemotherapy compared with the poor outcome following conventional chemotherapy. On the basis of these promising results, GITIL launched a prospective phase III randomized trial comparing the efficacy and safety of 8 cycles of RCHOP-14 with R-HDS regimen. ${ }^{21}$

R-HDS 0305 (Clinical Trials.gov.number NCT00355199) is a multicenter, unblinded, randomized, phase III trial involving 240 patients in 3 years from 18 Italian cancer centers, with DLBCL without CNS involvement, advanced stage (stage $\geq 2 \mathrm{II} \mathrm{B}$, bulk), age from 18 to 60 years, with ECOG-PS $=0-3$ and aaIPI 2-3 or age from 61 to 65 years with ECOG-PS $=0-2$ and IPI 3-5. The control group received RCHOP-14, which comprised 8 courses of chemotherapy every 14 days, supported by GCSF (day 7-11) plus IFRT for bulky or residual disease, if they achieved at least a PR after 4 cycles. Cases refractory to R-CHOP-14 were given R-HDS as salvage therapy. Experimental arm consisted in a R-HDS program, including a debulking phase of 3 courses of doxorubicin-containing chemotherapy (APO), followed by high-dose (hd)-cyclophosphamide (CTX) $7 \mathrm{~g} / \mathrm{sqm}$, hd-Ara$\mathrm{C}$ (2g/sqm every 12 hours for 6 days), hd-etoposide $2 \mathrm{~g} / \mathrm{sqm}$ plus cisplatin $100 \mathrm{mg} / \mathrm{sqm}$. After HDS chemotherapy, hdmitoxantrone plus melphalan (60 and $180 \mathrm{mg} / \mathrm{sqm}$ ) or BEAM (BCNU $300 \mathrm{mg} / \mathrm{sqm}$, etoposide $200 \mathrm{mg} / \mathrm{sqm}$, Ara-C $4000 \mathrm{mg} /$ sqm, L-PAM $140 \mathrm{mg} / \mathrm{sqm}$ ) conditioning regimen with ASCT plus IFRT for bulky or residual disease was planned. Rituximab (375 mg/sqm) is given for a total of 6 doses, twice after hd-CTX and hd-Ara-C, as in vivo purging before CD $34+$ cells harvest, and twice after ASCT. The primary outcomes of the study are CR, DFS, OS and EFS. From July 2005 to May 2008, 124 patients were enrolled in the study (R-CHOP-14=66; RHDS $=58$ ). The mean age was $47.2+12$ years and $\mathrm{M} / \mathrm{F}$ was 1.6. Patients presented with adverse features such as advanced stage (70\%), BM infiltration (35\%), bulky disease (70\%), elevated LDH (84\%), poor ECOG-PS (54\%), more than one extranodal sites (61\%), and 3-4 IPI risk factors (47\%). Until now 9 patients (7\%) did not complete the planned program. One patient, belonging to R-CHOP-14 arm was refractory to treatment and shifted to R-HDS salvage treatment, 5 died of disease progression and 3 of treatment related mortality (2.4\%). One more patient died 40 days after ASCT of intestinal perforation due to diverticolosis. Thus, the overall death rate was $7.3 \%$. Moreover, 5 patients recovered from severe adverse events: 2 acute respiratory distress, two graft failure and one acute cholangitis. The main G3-4 toxicity was hematological: anemia, granulocytopenia and thrombocytopenia, occurred in $34 \%, 41 \%$ and $21 \%$ of patients, respectively. Grade 2-3 gastointestinal toxicity and infectious episodes were recorded in $18 \%$ and $27 \%$ of patients, respectively.

Regarding the response rate and clinical outcome, the overall CR rate was $67 \%$ and the OS, EFS and DFS projected to 2 years were $65 \%, 58 \%$ and $80 \%$, respectively.

These preliminary data show that intensive programs such as dose-dense chemo-immunotherapy and R-HDS with ASCT are feasible until 65 years with an acceptable toxic profile, also on multi-centre basis. At completion of the trial we will assess the role of R-HDS and ASCT on the outcome of poor risk patients with DLBCL.

\section{Resumo}

Os pacientes com linforma de grande células B agora apresentam uma melhor evolução e longa sobrevida por causa de dois grandes desenvolvimentos: 1-Aumento da dose de drogas ativas e o espaço de tempo mais curto entre os ciclos, resultando deste fato uma dose mais consistente ou um regime com dose mais intensa. 2- Combinação da quimioterapia com o rituximab. Estas duas estratégias são associadas em uma melhoria da evolução clinica, particularmente dos pacientes que não apresentam fatores prognósticos adversos. Pacientes com risco pobre e com a idade ao redor dos 60 a 65 anos podem se beneficiar da combinação de dose ou do regime de dose intensificada mais rituximab. Pacientes jovens com risco pobre e que são definidos com IPI aa de 2 ou 3 e idade inferior a 60 anos são caracterizados como verdadeiramente refratários, sendo isto evidenciado pela progressão durante ou precocemente após o tratamento ou apresentam resposta tardia. Deve-se atentar para a modificação do tratamento e incluir imunoterapia para melhorar a taxa de resposta e reduzir a proporção de pacientes com doença em progressão. Atualmente a melhor sobrevida de progressão foi de 51\%. Devemos observar aspectos alvissareiros da diminuição da alta resistência e da taxa de recaida nos programas de quimioterapia seqüenciais de altas doses com rituximab e o transplante autólogo de células-tronco. O grupo italiano elaborou um estudo prospectivo randomizado de fase III comparando a eficácia e a segurança da dose intensa de CHOP mais rituximab com altas doses seqüenciais e rituximab seguido do transplante autólogo. Dados preliminares já mostram que os programas intensificados e o transplante autólogo são factiveis ate 65 anos com bom manuseio do efeito tóxico em todos os centros participantes. Rev. bras. hematol. hemoter. 2008; 30(Supl. 2):50-54.

Palavras-chave: Linfoma difuso de grandes células B; tratamento; prognóstico. 


\section{References}

1. Fisher RI, Gaynor ER, Dahlberrg S, Oken MM, Grogan TM, Mize EM et al. Comparison of a standard regimen (CHOP) with three intensive chemotherapy regimens for advanced non-Hodgkin's lymphoma. N Engl J Med. 1993;328:1002-6.

2. A predictive model for aggressive non-Hodgkin's lymphoma. The International Non-Hodgkin's Lymphoma Prognostic Factors Project. N Engl J Med. 1993;329:987-94.

3. Rosenwald A, Wright C, Chan WC, Connors JM, Campo E, Fisher RI et al. The use of molecular profiling to predict survival after chemotherapy for diffuse large B-cell lymphoma. N Engl J Med. 2002;346:1937-47.

4. Hans CP, Weisenberger DD, Greiner TC, Gayscone D, Delabie J, Ott G, et al. Confirmation of the molecular classification of diffuse large B-cell lymphoma by immunohistochemistry using a tissue microarray. Blood. 2004;103:275-82.

5. Pfreundschuh M, Truemper L, Marita Kloess M, Schimits R, Feller AC, Rudolph C et al, for the German High-Grade Non-Hodgkin's Lymphoma Study Group (DSHNHL). Two-weekly or 3-weekly CHOP chemotherapy with or without etoposide for the treatment of young patients with good-prognosis (normal LDH) aggressive lymphomas: results of the NHL-B1 trial of the DSHNHL. Blood 2004;104:626-33.

6. Pfreundschuh M, Truemper L, Marita Kloess M, Schimits R, Feller AC, Ruebe C, for the German High-Grade Non-Hodgkin's Lymphoma Study Group (DSHNHL). Two-weekly or 3-weekly CHOP chemotherapy with or without etoposide for the treatment of elderly patients with aggressive lymphomas: results of the NHLB2 trial of the DSHNHL. Blood 2004;104:634-41.

7. Philip T, Guglielmi C, Hagenbeek A, Somers R, Van der Lelie H, Bron $\mathrm{D}$ et al. Autologous bone marrow transplantation as compared with salvage chemotherapy in relapses of chemotherapy-sensitive non-Hodgkin's lymphoma. N Engl J Med 1995;333:1540-5.

8. Pettengell R, Radford JA, Mogenstern GR, Scarffe JH, Harris M, Woll PJ. Survival benefit from high-dose therapy with autologous blood progenitor-cell transplantation in poor-prognosis nonHodgkin's lymphoma. J Clin Oncol. 1996;14:586-92.

9. Vitolo U, Cortelazzo S, Liberati AM, Freilone R, Falda M, Bettini $\mathrm{M}$. Intensified and high dose chemotherapy with granulocyte colony-stimulating factor and autologous stem cell transplantation support as first line therapy in high-risk large cell lymphoma J Clin Oncol. 1997;15:491-8.

10. Cortelazzo S, Rossi A, Viero P, Bellavita P, Marchioli R, Marfisi R-M et al. BEAM chemotherapy and autologous haemopoietic progenitor cell transplantation as front-line therapy for high-risk patients with diffuse large cell lymphoma. Brit J Haematol. 1997; 99:379-85.

11. Greb A, Bohlius J, Trelle S, Schiefer D, De Souza C A, Gisselbrect C, et al. High-dose chemotherapy with autologous stem cell support in first-line treatment of aggressive non-Hodgkin lymphomaResults of a comprehensive meta-analysis. Cancer Treat Rev. 2007; $33: 338-46$.

12. Coiffier B, Haioun C, Ketterer N, ,Engert A.,Tilly H, Johnson P et al. Rituximab (anti-CD 20 monoclonal antibody) for the treatment of patients with relapsing or refractory aggressive lymphoma: A multicenter phase II study. Blood 1998;92:1927-32.

13. Vose JM, Link BK, Grossbard ML, Czuczman M, Grillo-Lopez A Gilman P et al. Phase II study of rituximab in combination with CHOP chemotherapy in patients with previously untreated, aggressive non-+Hodgkin's lymphoma J Clin Oncol 2001;19:389-97.

14. Coiffier B, Lepage E, Brière J, Herbrecht R, Tilly H, Bouabdallah $\mathrm{R}$ et al. CHOP chemotherapy plus rituximab compared with $\mathrm{CHOP}$ alone in elderly patients with diffuse large B-cell Lymphoma. N Eng1 J Med 2002:346:235-42.
15. Feugier P, Van Hoof A, Sebban C, Solal-Celigny P, Bouabdallah R, Fermé $\mathrm{C}$ et al. Long-term results of the R-CHOP study in the treatment of elderly patients with diffuse large B-cell lymphoma. J Clin Oncol 2005;23:4117-26.

16. Habermann TM, Weller EA, Morrison V A, Gayscone RD, Cassileth $\mathrm{PA}$, Cohn JB et al. Rituximab-CHOP versus CHOP alone or with maintenance rituximab in older patients with diffuse large B-cell lymphoma. J Clin Oncol 2006;24:3121-7.

17. Pfreundschuh M, Schubert J, Ziepert M, Scmits R, Moheren M, Lengfelder E et al. Six versus eight cycles of bi-weekly CHOP-14 with or without rituximab in elderly patients with aggressive $C D$ 20+ B-cell lymphomas: a randomized controlled trial (RICOVER60) Lancet Oncology. 2008;9:105-16.

18. Pfreundschuh M, Truemper L, Osterborg A, Pettengell R, Trneny $\mathrm{M}$, Imrie $\mathrm{K}$ et al. CHOP-like chemotherapy plus rituximab versus CHOP-like chemotherapy alone in young patients with goodprognosis diffuse large-B-cell lymphoma: a randomised controlled trial by the MabThera international Trial (MinT) Group. Lancet Oncology. 2006;7:379-91.

19. Sehn LH, Berry B, Chhanabhai M, Fitzgerald C, Gill K, Hoskins P et al. The revised International Prognostic Index (R-IPI) is better predictor of outcome than standard IPI for patients with diffuse large B-cell lymphoma treated with R-CHOP. Blood. 2007; 109:1857-61.

20. Tarella C, Zanni M, Di Nicola M, Patti C, Calvi R, Pescarollo A et al. Prolonged survival in poor-risk diffuse large B-cell lymphoma following front-line treatment with rituximab-supplemented, earlyintensified chemotherapy with multiple autologous hematopoietic stem cell support: a multicenter nstudy of GITIL (Gruppo Italiano Terapie Innovative nei Linfomi). Leukemia 2007;21:1802-11.

21. Cortelazzo S, Billio A, Rambaldi A, Tarella C, Majolino I, Gianni AM et al. A GITIL prospective randomized multicenter phase III study of high dose sequential chemotherapy with rituximab (RHDS and autologous transplantation (ASCT) of peripheral blood stem cells versus CHOP and rituximab delivered every 14 days (RCHOP-14) in high-risk patients with diffuse large B-cell lymphomas (DLBCL): interim analysis on feasibility and toxicity (protocol R-HDS 0305). Blood 2007;110:abstract1898.

O tema apresentado constou do programa do Encontro AIBE. Avaliadores: Professores Ângelo Maiolino, Cármino Antonio de Souza e Marcio Nucci.

Publicado após concordância do editor.

Conflito de interesse: não declarado.

Recebido: $13 / 05 / 2008$

Aceito: 13/05/2008 